\title{
PENGARUH DIVIDEN, HUTANG, RISIKO, LIQUIDITY, TANGIBILITY, COMPANY GROWTH, FIRM SIZE, DAN OVERINVESTMENT TERHADAP KINERJA PERUSAHAAN
}

\author{
Afnei Ngan Billy Tumba \\ Umi Murtini \\ Prodi Manajemen, Fakultas Bisnis Universitas Kristen Duta Wacana \\ Email korespondensi: umimt@staff.ukdw.ac.id
}

\begin{abstract}
ABSTRAK
Penelitian ini bertujuan untuk mengkaji kinerja perusahaan non keuangan di Indonesia. Teknik pengambilan sampel yang digunakan adalah purposive sampling, sedangkan teknik analisis yang digunakan dalam penelitian ini adalah regresi linier berganda. Sampel yang diambil adalah perusahaan non keuangan yang terdaftar di Bursa Efek Indonesia (BEI) periode 2015-2019. Perusahaan non keuangan yang diambil adalah perusahaan overinvestment dengan menggunakan metode Hodrick Prescott Fillter untuk menentukan perusahaan overinvestment. Pengukuran kinerja perusahaan menggunakan Basic Earning Power (BEP). Dari hasil penelitian overinvestment berpengaruh positif terhadap kinerja perusahaan. Risiko, dan Ukuran Perusahaan berpengaruh negatif terhadap kinerja perusahaan. Dividen, Hutang, Likuiditas, Tangibility, dan Pertumbuhan Perusahaan berpengaruh negatif terhadap kinerja perusahaan.
\end{abstract}

Kata Kunci: basic earning power, overinvestment, dividen, hutang, ukuran perusahaan

\begin{abstract}
This research aims to examine the performance of non-financial companies in Indonesia. The technique used for sampling was purposive sampling, while the analysis technique used in the study was multiple linear regression. Samples taken are non-financial companies listed on the Indonesia Stock Exchange (BEI) 2015-2019 period. Non-financial companies that are taken are overinvestment companies by using the Hodrick Prescott Fillter method to determine overinvestment companies. Measuring company performance using Basic Earning Power (BEP). From the research results, Overinvestment has a positive effect on company performance. Risk, and Firm Size have a negative effect on company performance. Dividend, Debt, Liquidity, Tangibility, and Company Growth have negative effect on company performance.
\end{abstract}

Keywords: basic earning power, overinvestment, dividend, debt, firm size 


\section{PENDAHULUAN}

Manajer keuangan bertugas membuat tiga kebijakan yaitu kebijakan hutang, dividen dan investasi (Trong, 2020). Kebijakan dividen menyangkut kepentingan perusahaan dan investor (Lumapow, 2017 dan Tumiwa, 2017). Jika perusahaan meningkatkan dividen maka arus kas perusahaan akan meningkat dan dapat menguntungkan investor namun akan sebaliknya jika laba perusahaan dibagi maka investasi perusahaan akan menurun dan akan merugikan investor (Tumiwa, 2019). Kebijakan hutang mengacu pada seberapa besar hutang perusahaan untuk leverage (Trong, 2020 dan Al-Najjar, 2018). Ketiga kebijakan keuangan ini berkaitan dalam menentukan kinerja perusahaan.

Kinerja perusahaan dipengaruhi oleh risiko, company growth, dividen, hutang, liquidity, tangibility, overinvestment, dan form size (Trong, 2020). Liquidity berkaitan dengan mengubah aktiva menjadi kas sehingga sering digunakan oleh perusahaan maupun investor untuk mengetahui tingkat kemampuan perusahaan dalam memenuhi kewajibannya, Liquidity perusahaan merupakan tolak ukur kemampuan aset lancar perusahaan dalam membiayai kewajiban jangka pendeknya (Murhadi, 2013). Liquidity dapat berkaitan dengan kondisi keuangan perusahaan, semakin kuatnya keuangan perusahaan dalam memenuhi kewajiban jangka pendek diikuti dengan risiko yang semakin tinggi dan akan berpengaruh terhadap kinerja perusahaan (Christian dan Pujiharto, 2013).

Risiko berkaitan dengan going concern perusahaan. Ada beberapa macam risiko perusahaan, yaitu risiko bisnis, risiko likuiditas, risiko tingkat bunga, risiko daya beli, dan risiko tingkat bunga (Halim, 2003). Risiko keuangan adalah risiko yang berkaitan dengan keputusan perusahaan untuk menggunakan pinjaman dalam pembiayaan modalnya. Semakin besar proporsi hutang yang digunakan, semakin besar risiko keuangan yang dihadapi perusahaan.

Assets tangibility merupakan aset tetap yang dimiliki perusahaan yang dapat dijadikan agunan hutang. Semakin besar nilai assets tangibility, maka semakin besar pula kemungkinan perusahaan mendapatkan pinjaman. Aset tetap yang digunakan sebagai jaminan memiliki peran penting dalam menentukan struktur modal perusahaan (Tornyeva, 2013).
Pertumbuhan penjualan disebabkan oleh perubahan harga, akuisisi maupun divestasi, perubahan nilai tukar, dan perubahan volume, semakin tinggi pertumbuhan penjualan perusahaan akan lebih aman dalam menggunakan hutang sehingga semakin tinggi struktur modalnya. Perusahaan yang memiliki pertumbuhan yang tinggi cenderung memperoleh modal kerja tambahan dengan menggunakan pinjaman atau hutang (Subramanyam, 2014).

Ukuran perusahaan (firm size) merupakan salah satu hal yang dipertimbangkan perusahaan dalam menentukan kebijakan hutangnya. Semakin besar ukuran perusahaan maka semakin besar dana investasi yang dapat diperoleh dari hutang. Semakin besar ukuran perusahaan maka semakin transparan pengungkapan kinerja perusahaan. Dengan demikian perusahaan menjadi semakin lebih mudah untuk mendapatkan pinjaman karena dipercaya kreditur (Mulianti, 2010). Penggunaan hutang atau pembayaran dividen cenderung akan mengurangi efek negatif dari overinvestment dengan mengurangi arus kas bebas yang berlebihan dalam perusahaan korporat. Namun kebijakan hutang dan kebijakan dividen saling menggantikan dapat mempengaruhi overinvestment dan dapat berhubungan dengan kinerja perusahaan.

Penggunaan hutang dan pembayaran dividen mengharuskan manajemen melakukan investasi yang efektif untuk meningkatkan profitabilitas perusahaan dan memenuhi komitmen perusahaan, tidak hanya kepada debtholders tetapi juga dengan stockholders. Penerapan kebijakan investasi dengan kebijakan dividen dan hutang membagi pengawasan dengan berbagai pihak pasar modal, sehingga mengurangi beban perusahaan. Oleh karena itu masalah overinvestment dapat diatasi dengan merencanakan dividen, hutang, dan investasi secara bersama-sama dan menyesuaikan salah satu dari ketiganya untuk menjaga profitabilitas perusahaan dan menjaga kinerja dari perusahaan (DeAngelo, 2006).

Masalah overinvestment berkaitan dengan kemungkinan manajemen menyalahgunakan kekuasaannya dalam mengambil keputusan dengan mengadopsi proyek yang tidak menguntungkan atau terlalu berisiko yang dapat merusak kepentingan pemegang saham serta kepentingan para 
debtholders. Masalah manajerial overinvestment disebabkan oleh konflik antara manajer dan pemegang saham, dengan proyek yang berisiko. Konflik antara manajer dan pemegang saham dapat muncul ketika manajemen dianggap tidak optimal dalam mengambil keputusan (Rocca, 2007). Overinvestment berhubungan negatif dengan profitabilitas perusahaan. Kebijakan hutang dan dividen dapat memoderasi dampak buruk dengan mengurangi arus kas bebas yang berlebihan (Trong, 2020).

\section{KAJIAN LITERATUR DAN PENGEMBANGAN HIPOTESIS}

\section{Kebijakan Dividen}

Kebijakan dividen (dividend policy) adalah keputusan apakah laba yang di peroleh perusahaan akan dibagikan kepada pemegang saham sebagai dividen atau akan ditahan dalam bentuk laba ditahan guna pembiayaan investasi untuk masa depan perusahaan yang akan datang. Besar kecilnya dividen yang akan dibagikan oleh perusahaan tergantung pada kebijakan dari masing-masing perusahaan, sehingga pertimbangan manajemen sangat diperlukan. Dalam aktivitas di pasar modal, para investor memiliki harapan dari investasi yang dilakukan yaitu berupa dividend dan capital gain (Sulistiyowati, 2014).

Setiap perubahan dalam kebijakan pembagian akan mempunyai pengaruh yang saling bertentangan. Dengan demikian, kebijakan deviden yang optimal dapat diartikan sebagai kebijakan yang menciptakan keseimbangan di antara dividen saat ini dan pertumbuhan di masa mendatang yang memaksimumkan harga saham (Brigham, 2005).

\section{Kebijakan Hutang}

Posisi hutang perusahaan mengindikasikan jumlah uang yang dimiliki pihak eksternal untuk menghasilkan profit (Gitman, 2003). Kebijakan hutang dalam rangka memperoleh sumber pembiayaan bagi perusahaan digunakan untuk membiayai aktivitas operasional perusahaan (Tjeleni, 2013). Hutang sebagai sumber pendanaan ekspansi, dan digunakan untuk mengurangi konflik keagenan. Perusahaan memerlukan dana yang besar dalam mendanai belanja modal perusahaan. Sumber pendanaan tersebut dapat diperoleh dari internal yaitu laba ditahan sedangkan eksternal dengan melakukan pinjaman dalam bentuk hutang atau menerbitkan saham di pasar modal. Metode pendanaan ini akan menentukan struktur kapital/modal perusahaan (Maulana, 2017).

Perusahaan yang berhutang diharuskan membayar bunga hutang dan pokok hutang secara periodik. Bunga hutang tersebut ini menjadi pengurang nilai laba kena pajak. Dalam mengurangi nilai laba kena pajak perusahaan akan melakukan interest tax shield. Interest tax shield merupakan manfaat penggunaan hutang dari sisi perpajakan. Oleh karena itu, semakin tinggi hutang perusahaan, semakin tinggi pula nilai bunga hutang sehingga nilai laba kena pajak juga semakin menurun. Sebelum kreditur memberikan dana pada perusahaan, kreditur harus mengetahui terlebih dahulu apakah perusahaan yang akan menjadi debiturnya memiliki kemampuan untuk membayar hutang dan bunganya atau tidak dimasa depan, sehingga informasi itu akan bermanfaat bagi kreditur untuk membuat keputusan apakah ia akan meminjamkan dana atau tidak untuk perusahaan sesuai dengan informasi yang diterimanya. Keberadaan hutang yang besar dapat menyebabkan kerugian bagi perusahaan sehingga menyulitkan perusahaan sebagai debitur dalam membayar hutangnya kepada kreditur. Perusahaan memiliki risiko kebangkrutan oleh karena kesulitan finansial yang dihadapi.

\section{Risiko}

Definisi dari risiko berbeda-beda, tergantung pada tujuannya. Definisi risiko yang tepat menurutnya dilihat dari sudut pandang adalah, exposure terhadap ketidakpastian pendapat (Eddie, 2002). Risiko dapat dimaknai sebagai potensi terjadinya suatu peristiwa yang dapat menimbulkan kerugian. Dalam investasi, risiko didefinisikan sebagai kemungkinan hasil uang yang diperoleh menyimpang dari yang diharapkan (Tony, 2011).

Risiko merupakan hal yang pasti dihadapi oleh perusahaan ketika menjalani kegiatan operasinya, yaitu kemungkinan ketidakmampuan perusahaan untuk mendanai kegiatan operasionalnya. Risiko berpengaruh terhadap kelangsungan bisnis usaha perusahaan 
dan kemampuan perusahaan membayar hutangnya (Farah, 2010).

\section{Liquidity}

Semakin tinggi likuiditas menunjukkan perusahaan tersebut semakin mampu memenuhi kewajibannya saat jatuh tempo. Tingkat likuiditas tinggi pada perusahaan yang buruk dalam jangka panjang akan mempengaruhi solvabilitas perusahaan yang mengakibatkan akan menurunkan profit perusahaan (Khan, 2017).

\section{Tangibility}

Tangibility berhubungan dengan jumlah kekayaan (asset) yang dapat dijadikan jaminan, hal ini dipandang sebagai cara untuk mengurangi risiko kreditur. Semakin besar proporsi Tangibility perusahaan, maka kreditur akan lebih mudah memberikan pinjaman sehingga tingkat hutang menjadi semakin besar (Antao, 2012). Teori teori size effect menyatakan perusahaan dengan tangibility besar akan menggunakannya sebagai jaminan untuk memperoleh hutang. Tnagibility memiliki efek positif yang menunjukkan bahwa aset berwujud yang mudah dipantau dan memberikan jaminan yang baik, maka akan mengurangi konflik keagenan antara pemegang saham dan kreditur. Efek negatif yang dihasilkan tangibility terhadap kinerja perusahaan karena perusahaan dengan tingkat aset berwujud yang banyak cenderung kurang menguntungkan karena biaya modal yang dikeluarkan akan meningkat sehingga akan menurunkan keuntungan perusahaan (Skandalis, 2007).

Rasio tangibility mengukur pembiayaan aktiva tetap menggunakan modal ekuitas. Tingginya rasio tangibility menunjukkan ketidakefisienan penggunaan modal kerja (Skandalis, 2007). Perusahaan dengan asset tangibility yang dapat digunakan sebagai jaminan, cenderung menggunakan lebih banyak hutang. Perusahaan yang besar akan lebih mudah mendapatkan akses ke sumber dana dibandingkan perusahaan yang kecil (Oni, 2014).

\section{Company Growth}

Yuniningsih (2002), perusahaan dengan growth tinggi menghasilkan keuntungan yang tinggi juga. Hal ini membuktikan bahwa semakin tinggi pertumbuhan perusahaan dapat meningkatkan kinerja perusahaan. Pertumbuhan perusahaan berpengaruh positif terhadap kinerja keuangan karena peningkatan aset menjadi sinyal positif bagi investor (Morck, 1988).

\section{Firm Size}

Firm size merupakan besaran aset dimiliki perusahaan yang digunakan untuk kegiatan operasi usahanya. Firm size adalah besar kecilnya ukuran perusahaan yang dapat dilihat dari total asetnya. Perusahaan dikatakan besar jika total aktiva yang dimiliki besar dan dapat memberikan keuntungan bagi perusahaan yang memiliki akses yang lebih baik dalam mengembangkan usahanya. Besarnya aset dikarenakan investasi besar yang dilakukan perusahaan sehingga memberikan dampak yang baik dengan menghasilkan laba tinggi (Lazar, 2016).

\section{Overinvestment}

Overinvestment berdampak pada penurunan profitabilitas perusahaan pengembalian aset yang lebih rendah (Lin, 2016). Manajer cenderung meningkatkan skala usaha meski harus mengambil proyek yang kurang menguntungkan. Perilaku manajemen semacam ini dapat dicegah dengan meningkatkan leverage. Nilai perusahaan berhubungan negatif dengan leverage pada perusahaan dengan high growth opportunity. Nilai perusahaan berhubungan positif dengan leverage dengan low growth opportunity (Servaes, 1995).

\section{Pengembangan Hipotesis}

Arus kas bebas yang berlebihan menciptakan peluang bagi manajer untuk mendapatkan keuntungan dengan menggunakan data diskresioner untuk meningkatkan sumber daya di bawah kendali dan meningkatkan posisi dengan lebih banyak investasi (Shi, 2019). Oleh karena itu, pengurangan arus kas bebas merupakan solusi atas perilaku ekspropriasi para manajer (Jensen, 1976 dan Ali, 1976). Kebijakan dividen dapat membantu menahan efek buruk overinvestment dengan arus kas bebas yang lebih rendah. Penurunan overinvestment dapat meningkatkan nilai perusahaan dan meningkatkan pembayaran dividen (Litzenberger, 1989). Semakin besar dividen dibagika akan 
menurunkan kinerja perusahaan (Sjahrial, 2007). Maka disusun hipotesis:

$\mathrm{H}_{1}=$ Dividen berpengaruh negatif terhadap BEP.

Kebijakan hutang dapat membantu overinvestment dengan arus kas bebas yang lebih rendah di perusahaan menurut penelitian yang dilakukan oleh (Jensen, 1976). Penggunaan hutang dapat mengakibatkan kesulitan keuangan atau bahkan kebangkrutan yang lebih buruk (Grossman, 1982). Maka hipotesis kedua:

$\mathrm{H}_{2}=$ Hutang berpengaruh negatif terhadap BEP .

Terjadinya pengaruh negatif risiko terhadap kinerja perusahaan karena perusahaan menggunakan modal sendiri untuk menghindari risiko dalam menginvestasikan modalnya. Memperluas bisnis yang baru meningkatkan risiko bisnis, semakin tinggi risiko perusahaan maka semakin tinggi tingkat kesulitan keuangan dan menurunkan kinerja. Berdasar argumentasi tersebut, disusunt hipotesis ketiga:

$\mathrm{H}_{3}=$ Risiko berpengaruh negatif terhadap BEP.

Pengaruh positif antar liquidity dengan kinerja perusahaan menurut penelitian yang dilakukan (Charumathi, 2012). Hal ini menunjukkan tingkat liquidity yang tinggi menunjukkan perusahaan tersebut semakin mampu dalam memenuhi kewajibannya pada saat jatuh tempo sehingga perusahaan akan memiliki dana yang tersedia dalam bentuk investasi yang bisa dipergunakan untuk mengembangkan kegiatan operasional perusahaan sehingga dapat meningkatkan keuntungan yang maksimum bagi perusahaan dan menunjukkan kinerja keuangan perusahaan akan semakin baik. Maka dapat dibuat hipotesis keempat:

$\mathrm{H}_{4}=$ Liquidity berpengaruh positif terhadap BEP.

Perusahaan dengan tingkat aset berwujud besar cenderung kurang menguntungkan karena biaya modal yang dikeluarkan akan meningkat sehingga akan menurunkan keuntungan (Skandalis, 2007). Rasio tangibility mengukur pembiayaan aktiva tetap menggunakan ekuitas. Tingginya rasio tangibility menunjukkan tidak efisiennya penggunaan modal kerja yang biasanya berarti cadangan kas yang rendah. Rasio tangibility yang tinggi menunjukkan bahwa tidak efisien dalam penggunaan struktur modal dimana membatasi kemampuan perusahaan dalam menanggapi peningkatan permintaan yang akan memperoleh kinerja perusahaan (Skandalis, 2007). Maka, dapat dibuat hipotesis kelima :

$\mathrm{H}_{5}=$ Tangibility berpengaruh negatif terhadap BEP.

Pertumbuhan perusahaan berpengaruh positif terhadap kinerja perusahaan. Peningkatan aset perusahaan merupakan sinyal positif bagi investor, karena pertumbuhan perusahaan dibaca sebagai keberhasilan manajemen mengelola perusahaan dengan baik dan benar. Maka disusun hipotesis:

$\mathrm{H}_{6}=$ Company Growth berpengaruh positif terhadap BEP.

Firm size berpengaruh negatif terhadap kinerja perusahaan (Kinanti, 2009). Jumlah aset yang dimiliki kurang didukung dengan pengelolaan manajemen yang baik bisa menurunkan kinerja (Isbanah, 2015). Hipotesis ke tuju :

$\mathrm{H}_{7}=$ Firm Size berpengaruh negatif terhadap BEP.

Masalah keagenan yang membatasi akses pembiayaan serta memburuk kinerja perusahaan (Yang, 2016). Overinvestment berhubungan negatif dengan kinerja perusahaan (Trong, 2020 dan Liu, 2010). Maka, disusun hipotesis penelitian:

$\mathrm{H}_{8}=$ Overinvestment berpengaruh negatif pada BEP.

\section{METODE}

\section{Populasi dan Metode Sampling}

Populasi dari penelitian ini adalah semua perusahaan go public yang tercatat di Bursa Efek Indonesia (BEI). Metode sampling digunakan purposive sampling dengan kriteria adalah:

1. Perusahaan non keuangan.

2. Membagikan dividen secara berturut-turut selama lima tahun tahun 2015 sampai 2019.

3. Perusahaan memiliki hutang dari tahun 2015 sampai 2019. 
4. Perusahaan memiliki overinvestment.

\section{Variabel}

Variabel dependen kinerja perusahaan diukur menggunakan rasio Basic earning power (BEP) dihitung dengan menggunakan rumus:

$$
B E P=\frac{\text { Earning Before Interest and Tax (EBIT) }}{\text { Total Asset }}
$$

Variabel Independen

1. Risiko (Risk)

Risiko dilihat dari standar deviasi EBITDA terhadap rasio aset dari tahun ke tahun, dan debt ratio yang diambil dari total kewajiban atas total aset. Risiko ditung dengan rumus:

$$
\text { Std.Dev }=\sqrt{\frac{\sum_{i=1}^{n}\left(x_{i}-\mu\right)^{2}}{n}}
$$

Keterangan:

$\chi_{\mathrm{i}}=$ nilai $\mathrm{x}$ ke 1

$\mu=$ rata-rata populasi

$\mathrm{n}=$ jumlah data

2. Pertumbuhan Penjualan (Company Growth) Pertumbuhan penjualan diukur dengan tingkat pertumbuhan terhadap total penjualan:

$$
\text { growth }=\frac{{\text { net } \text { sales }_{t}-\text { net sales }}_{t-1}}{\text { net sales }}
$$

\section{Dividen (Dividend)}

Dividen diukur menggunakan cash dividend pay-out atas laba setelah pajak (earning after tax):

$$
D P R=\frac{\text { Total Cash Dividend Payout }}{\text { Earning After Tax }(\text { EAT })}
$$

\section{Hutang (Debt)}

Hutang diukur menggunakan rasio solvabilitas:

$$
\text { DTR }=\frac{\text { Total Liabilities }}{\text { Total Asset }}
$$

\section{Likuiditas (Liquidity)}

Likuditas diukur dengan menggunakan quick ratio:

$$
\text { Liquidity }=\frac{\text { (current asset }- \text { inventories })}{\text { current liabilities }}
$$

6. Tangibility

Tangibility diukur dengan tangible fixed assets dibagi dengan total aset:

$$
\text { Liquidity }=\frac{(\text { current asset }- \text { inventories })}{\text { current liabilities }}
$$

7. Investasi Berlebih (Overinvestment)

Overinvestment diukur menggunakan metoda Hodrick-Prescott Filter:

Investment $t_{i, t}^{\text {New }}=$ DebtRatio + Risk + CompanySize + SalesGrowth + AssetTurnover + Growth0ption + CashFlow $+V_{i, t}$

8. Ukuran Perusahaan (Firm Size)

Ukuran perusahaan di proksikan dengan logaritma (Ln) dari total aset:

$$
\text { Size }=\ln (\text { Total Asset })
$$

\section{Uji Hipotesis}

Uji hipotesis digunakan regresi berganda dengan persamaan:

$$
\begin{aligned}
\text { Performance }_{i, t} & =\lambda_{0}++\lambda_{1} \text { Size }_{i, t}+\lambda_{2} \text { Growth }_{i, t}+\lambda_{3} \text { Risk }_{i, t} \\
& +\lambda_{4} \text { Liquidity }_{i, t}+\lambda_{5} \text { Tangibility }_{i, t}+\lambda_{6} \text { Dividend }_{i, t} \\
& +\lambda_{7} \text { Debt }_{i, t}+\lambda_{8} \text { Overinvestment }_{i, t}+\mu_{i, t}
\end{aligned}
$$

\section{Hodrick-Prescott Filter (HP Filter)}

HP Filter digunakan untuk mengukur overinvestmet. Nilai rill investasi dikurangi dari investasi HP Filter. Overinvestment diukur dengan persamaan:

$\min _{T_{\left\{g_{t}\right\}_{t=1}}} \sum_{t=1}^{T}\left[\left(y_{t}-g_{t}\right)^{2}+\lambda\left[\left(g_{t+1}-g_{t}\right)-\left(g_{t}-g_{t-1}\right)\right]^{2}\right]$

\section{Pemilihan Sampel}

Pemilihan sampel menggunakan purposive sampling diperoleh hasil seperti dalam Tabel 1: 
Tabel 1. Seleksi Sampel

\begin{tabular}{lc}
\hline \multicolumn{1}{c}{ Keterangan } & Jumlah Perusahaan \\
\hline Perusahaan di Indonesia yang tercatat di BEI & 629 \\
Perusahaan non keuangan di Indonesia yang tercatat di BEI & 588 \\
Perusahaan non keuangan di Indonesia yang tidak membagikan dividen & $(479)$ \\
lima tahun berturut-turut dari tahun 2015 sampai 2019 & \\
Perusahaan non keuangan di Indonesia yang membagikan dividen lima & 109 \\
tahun berturut-turut dari tahun 2015 sampai 2019 & \\
Perusahaan non keuangan di Indonesia yang underinvestment & $(67)$ \\
Perusahaan non keuangan di Indonesia yang overinvestment & 42 \\
\hline
\end{tabular}

Sumber: Data diolah

Dari Tabel 1 diperoleh hasil perusahaan yang akan diteliti sebanyak 42 perusahaan.
Gambaran data penelitian dapat dilihat dalam hasil statistik deskripsi di Tabel 2 di bawah ini:

\section{HASIL PENELITIAN DAN} PEMBAHASAN

Tabel 2. Deskriptif Statistik

\begin{tabular}{lccccccccc}
\hline & Bep & Dpr & Debt & Risk & Liquidity & Tangibility & Growth & Size & Over \\
\hline Mean & 0.140035 & 0.495944 & 0.429800 & 0.028282 & 1.546904 & 0.321363 & 0.100029 & 6.112293 & 0.844566 \\
Median & 0.099762 & 0.371531 & 0.421917 & 0.014243 & 1.222745 & 0.292819 & 0.007073 & 6.092145 & 0.617081 \\
Maximum & 0.711433 & 0.758150 & 0.810814 & 0.233945 & 7.357361 & 0.866214 & 2.628260 & 7.403445 & 3.788081 \\
Minimum & 0.007762 & 0.016473 & 0.053239 & 0.000695 & 0.202784 & 0.007166 & -0.521253 & 4.876610 & 0.013605
\end{tabular}

Sumber: Data diolah

Dari Tabel 2, terlihat bahwa perusahaan yang menjadi sampel penelitian mendapatkan keuntungan setiap tahun selama tahun penelitian, karena tidak didapatkan nilai negative di variable BEP. Perusahaan membagi deviden cukup tinggi sampai dengan $75,81 \%$, minimal deviden yang dibagikan $10 \%$ dari total keuntungan setelah pajak perusahaan. Struktur modal perusahaan maksimum didanai berasal dari hutang sebesar 81\%, sehingga menunjukkan cukup besar risiko perusahaan ini. Pertumbuhan perusahaan ada yang negatif, berarti perusahaan mengalami penurunan penjualan. Perusahaan paling tinggi mengalami over investment sampai dengan 3,78 kali dari investasi yang seharusnya.

Dari pemilihan model regresi yang tepat dan uji asumsi klasik yang telah dilakukan, maka diperoleh model regresi yang tepat Fixed Effect Model. Hasil olah data regresi yang bebas asumsi klasik dapat dilihat dalam Tabel 3 di bawah:

Tabel 3. Fixed Effect Model

\begin{tabular}{lcc}
\hline Variable & Coefficient & t-Statistic \\
\hline DPR & -0.027503 & $-3.475601^{* * *}$ \\
DEBT & -0.032908 & $-2.616833^{* * *}$ \\
& & \\
RISK? & -1.650877 & $-3.708860^{* * *}$ \\
LIQUIDITY & 0.000786 & $2.143812^{* *}$ \\
TANGIBILITY & -0.028950 & $-2.394885^{* *}$ \\
GROWTH & 0.010630 & $1.477905^{*}$ \\
SIZE & -0.083230 & $-2.357142^{* *}$ \\
OVER & 0.101948 & $5.178585^{* * *}$ \\
\hline
\end{tabular}

Sumber: Data diolah

Keterangan: ***Signifikan pada alfa $1 \%$

** Signifikan pada alfa 5\% 
Dividen berpengaruh negatif terhadap kinerja perusahaan (BEP). Semakin besar deviden yang dibagikan, maka akan menurunkan keuntungan perusahaan sehingga nilai BEP semakin kecil. Dengan deviden yang dibagi semakin besar maka perusahaan harus menutup kekurangan dana untuk operasi dan investasi dengan menggunakan hutang. Peningkatan hutang akan meningkatkan biaya modal perusahaan dan meningkatkan beban tetap berupa bunga. Sehingga dapat menurunkan keuntungan perusahaan. Hal ini didukung dengan terbuktinya hipotesis ke dua, yaitu hutang berpengaruh negative terhadap kinerja perusahaan. Peningkatan hutang juga dianggap meningkatkan risiko perusahaan. Semakin tinggi risiko perusahaan akan menurunkan kinerja perusahaan. Hal ini terbukti dengan terdukungnya hipotesis ke tiga yaitu risiko berpengaruh negative terhadap kinerja perusahaan. Dalam hal ini tidak berlaku high risk high return, karena peningkatan risiko perusahaan yang diukur dari perubahan penjualan akan menurunkan keuntungan perusahaan. Maka kenaikan hutang yang dilakukan untuk menambah dana mendukung operasional dan ekspansi perusahaan akan meningkatkan risiko perusahaan dan menurunkan keuntungan perusahaan. Pada perusahaan yang melakukan investasi berlebih (overinvestment) dapat membuat hutang perusahaan berpengaruh negatif terhadap kinerja perusahaan, pada keadaan ini perusahaan yang melakukan investasi berlebih (overinvestment) berarti perusahaan cenderung melakukan investasi dalam proyek yang tidak menguntungkan dan manajemen perusahaan tidak efektif, dalam keadaan seperti ini perusahaan berada pada keadaan risiko kesulitan keuangan dan kebangkrutan yang lebih tinggi yang memaksa perusahaan untuk meningkatkan efisiensi dan membatasi kewajiban hutangnya. Pada akhirnya perusahaan sama-sama membayar dividen dan memiliki masalah investasi berlebih (Trong, 2020).

Likuiditas berpengaruh positif terhadap kinerja perusahaan (BEP). Perusahaan semakin likuid, menunjukkan semakin besar ketersediaan dana untuk mendukung operasional perusahaan. Ketersediaan dana ini mendukung kelancaran operasional dan peningkatan keuntungan perusahaan. Hal ini terdukung dengan teori liquidity, semakin tinggi likuiditas suatu perusahaan maka menunjukkan perusahaan tersebut semakin mampu dalam memenuhi kewajibannya pada saat jatuh tempo dan perusahaan tersebut dinyatakan likuid serta mampu dalam memenuhi kewajibannya, sehingga perusahaan akan memiliki dana yang tersedia dalam bentuk investasi yang bisa dipergunakan untuk mengembangkan kegiatan operasional perusahaan sehingga dapat meningkatkan keuntungan maksimum bagi perusahaan dan menunjukkan kinerja keuangan perusahaan akan semakin baik. Akan tetapi tingkat likuiditas tinggi pada perusahaan yang buruk dalam jangka panjang akan mempengaruhi solvabilitas perusahaan yang mengakibatkan akan menurunkan profit perusahaan (Khan, 2017). Tangibility berpengaruh negatif terhadap kinerja (BEP). Semakin besar tangibility maka perusahaan akan semakin besar menanggung biaya tetap. Pada tingkat penjualan berapapun, biaya tangibility tetap besarannya sehingga keuntungan perusahaan akan menurun (BEP menurun). Besarnya tangibility terutama bila tangibility tersebut menganggur, tidak digunakan secara optimal maka akan menyebabkan biaya perusahaan besar. Hasil penelitian sejalan dengan teori tangibility, pengaruh efek tangibility terhadap kinerja perusahaan karena perusahaan dengan tingkat aset berwujud yang banyak cenderung kurang menguntungkan karena biaya modal yang dikeluarkan akan meningkat sehingga akan menurunkan keuntungan perusahaan Jika suatu perusahaan memiliki aset tetap yang banyak maka hal tersebut tidak dapat menjamin adanya penghasilan yang akan dihasilkan oleh perusahaan mengakibatkan kinerja perusahaan menurun dan tidak adanya pengembalian aset yang maksimal di dalam perusahaan tersebut. Penelitian ini sejalan dengan penelitian yang dilakukan oleh (Getahun, 2016).

Pertumbuhan (growth) berpengaruh positif terhadap kinerja perusahaan (BEP). Semakin tinggi pertumbuhan perusahaan akan semakin tinggi pula keuntungan perusahaan, sehingga meningkatkan kinerja perusahaan. Sejalan dengan teori company growth, suatu pertumbuhan yang lebih baik jika terdapat peningkatan yang konsisten dalam aktivitas utama operasinya. Perusahaan dengan pertumbuhan positif adalah indikator majunya perusahaan tersebut. Company growth merupakan pertumbuhan penjualan yang 
dialami oleh perusahaan dalam beberapa periode menunjukkan tingkat kesuksesan sebuah perusahaan yang diikuti dengan peningkatan pendapatan yang akan berdampak terhadap kinerja perusahaan, tingkat penjualan yang tinggi dihasilkan oleh perusahaan, dengan tingkat penjualan yang tinggi perusahaan akan memiliki kinerja perusahaan yang baik. Penelitian ini sejalan dengan penelitian yang dilakukan oleh (Mappanyuki, 2017).

Firm size berpengaruh negatif terhadap kinerja perusahaan (BEP). Penelitian ini sesuai dengan teori trade-off theory. Perusahan berhutang sampai pada tingkat hutang tertentu, sehingga mendapatkan penghematan pajak (tax shields) dari tambahan hutang. Perusahaan besar yang overinvestment menunjukkan nilai labanya banyak di bagikan sebagai dividen. Hal ini sesuai dengan hasil penelitian Isbanah (2015).

Overinvestment berpengaruh positif terhadap kinerja perusahaan (BEP). Agency theory menyatakan konflik kepentingan manajer dan pemegang saham. Manajer berinvestasi pada proyek yang tidak menguntungkan dan menyebabkan investasi berlebih (overinvestment) seperti perusahaan tidak menggunakan hutang tetapi membagi dividen kepada pemegang saham, menggunakan hutang tetapi tidak membagikan dividen kepada pemegang saham, atau tidak menggunakan hutang dan tidak membagikan dividen kepada pemegang saham, hal ini dapat berpengaruh buruk terhadap kinerja perusahaan. Dalam hal ini perusahaan yang diteliti tidak terjadi permasalahan dalam manajerial perusahaan, manajer tidak melakukan proyekproyek yang tidak menguntungkan, sehingga investasi berlebih (overinvestment) yang terjadi tidak berpengaruh negatif terhadap kinerja perusahaan (Yao, 2020). Overinvestment berpengaruh positif jika perusahaan menggunakan hutang pada struktur modal dan membagikan dividen berturut-turut kepada pemegang saham. Kebijakan hutang dan kebijakan dividen dapat mengurangi efek negatif investasi berlebih (overinvestment) terhadap kinerja perusahaan menurut hasil penelitian yang dilakukan oleh (Trong, 2020).

\section{SIMPULAN DAN SARAN}

\section{Simpulan}

Dari analisis di atas maka dapat disimpulkan bahwa perusahaan yang over investment di Indonesia memiliki kebijakan deviden, hutang, tangibility, Risiko dan ukuran perusahaan berpengaruh negative terhadap kinerja perusahaan, sedangkan pertumbuhan, likuiditas dan over investment berpengaruh positif terhadap kinerja perusahaan. Diduga perusahaan di Indonesia menganut teori struktur modal trade-off theory.dan mendukung teori liquidity serta agency theory.

\section{Keterbatasan}

Keterbatasan penelitian ini adalah penelitian hanya meneliti perusahaan yang overinvestment dengan menghitung berdasar metode Hodrick Prescott Fillter. Peneliti tidak meneliti perusahaan yang underinvestment.

\section{Saran}

Penelitian berikutnya perlu pula diteliti untuk perusahaan yang underinvestment supaya dapat memberi masukan bagi invertor maupun manajer dalam mengambil kebijakan perusahaan terutama dalam perusahaan yang melakukan over maupun under investment.

\section{REFERENSI}

Ali, M. J. (2019). Do Corporate General Counsels Mitigate Agency Problems? Evidence from Dividend Policy Decisions. Department of Economics, Finance and Marketing,La Trobe University, 1-52.

Al-Najjar, B. (2018). What Do We Know About the Dividend Puzzle? - A Literature Survey* . Forthcoming in International Journal of Managerial Finance, 205.

Birundu, M. M. (2015). The Effect of Capital Structure on the Financial Performance of Small and Medium Enterprises in Thika Sub-County, Kenya. International Journal of Humanities and Social Science, Vol. 5. No. 1, Pp. 151-156.

Bredin, N. L. (2010). Institutional Investors, Over-investment and Corporate Performance. University College. 
Charumathi. (2012). On the Determinants of Profitability of Indian Life Insurers - An Empirical Study. Proceedings of the World Congress on Engineering, 4-9.

Fajri, G. R. (2018). The Effect Of Rentability Ratio, Solvability Ratio, Liquidity Ratio Upon The Company's Value (Emperical Study of Mining Companies Sub Sector of Metal and Other Mineral Registered in The Indonesia Stock Exchange In 20122016). The Accounting Journal of BINANIAGA Vol. 03, No. 01, 39-50.

Getahun. (2016). Capital Structure an Financial Performance of Insurance Insudtries in Ehiopia. Global Journal of Management and Business Research 16(7), 45-53.

Handayani. R, d. S. (2011). Menentukan Struktur Modal Perusahaan Manufaktur Di Bursa Efek Indonesia Determinant Of Capital Structure On The Manufacturing Company Capital In Indonesia Stock Exchange. Dinamika Keuangan dan Perbankan, 172-182.

Harjito, D. A. (2011). Teori Pecking Order Dan Trade-Off Dalam Analisis Struktur Modal Di Bursa Efek Indonesia. Jurnal Siasat Bisnis, 187-196.

Isbanah, Y. (2015). Leverage dan Ukuran Perusahaan Terhadap Kinerja Keuangan Perusahaan di Bursa Efek Indonesia. Journal of $f$ Researh in Ekonomics and Management Vol. 15 No.1, 28-41.

Jensen, M. a. (1976). Theory of the firm: Managerial behavior, agency cost and ownership structure. Journal of Finance Economic 3, 305-360.

Kimura, M. \&. (2017). The Effect of Sales Growth Ratio, Inventory Trun Over Ratio, Growth Opportunity to Company's Profitability (Survey in Indonesia's Stock Exchange). International Journal of Management and Appled Science 3 (3), 137-147.

Lin, Y.-C. (2016). Do Voluntary Clawback Adoptions Curb Overinvestment? Wiley Journal, 255-270.

Lina, J. d. (2010). Faktor-Faktor yang Mempengaruhi Struktur Modal. Jurnal Bisnis dan Akuntansi, 81-96.
Lumapow, L. S. (2017). The Effect of Dividend Policy, Firm Size, and Productivity to The Firm Value. Research Journal of Finance and Accounting, 20-24.

Maulana, Z. (2017). Pengaruh Hutang Jangka Pendek dan Hutang Jangka Panjang Terhadap Profitabilitas pada PT. Bank Mandiri Tbk. Jurnal Mix 4 (1), 1.

Oni, O. (2014). Assessing The Impact Of Asset Tangibility On Capital Structure : Choice For Listed Firms In Nigeria. Journal Of Applied Economics and Business, Vol. 2, No., 5-20.

Rocca, M. L. (2007). Overinvestment And Underinvestment Problems: Determining Factors, Consequences And Solutions. Corporate Ownership \& Control 5, 80.

Shi, M. (2019). Overinvestment and corporate governance in energy listed companies: Evidence from China. Finance Research Letters, 436-445.

Sitanggang. (2013). Manajemen Keuangan Perusahaan Lanjutan. Jakarta: Mitra Wacana Media.

Sulistyowati, A. S. (2014). Pengaruh Struktur Modal Terhadap Kebijakan Dividen.Jurnal Administrasi Bisnis. Jurnal Manajemen Bisnis Indonesia, Vol 8 no.2.

Trong, N. N. (2020). Firm performance: the moderation impact of debt and dividend policies on overinvestment. Journal of Asian Business and Economic Studies.

Wibowo, A. (2012). Peran Kinerja Perusahaan dan Risiko Sistematis dalam Menentukan Pengaruh Inflasi Terhadap Nilai Perusahaan. Media Ekonomi dan Manajemen, 1-16.

Yang, A. G. (2016). A balancing act: Managing financial constraints and agency coststo minimize investment inefficiency in the Chinese market. Journal of Corporate Finance, 111-130.

Yao.Y, Z. Z. (2020). The role of political connection on overinvestment of Chinese energy firm. Energy Economics, 85, 104516. 
JRAK, Volume 17, No.1 Februari 2021 